\title{
Management of Library Course Reserves and the Textbook Affordability Crisis
}

\author{
JOHN H. POLLITZ \\ University of Wisconsin-Eau Claire, Eau Claire, WI \\ ANNE CHRISTIE \\ University of Alaska Fairbanks, Fairbanks, AK \\ CHERYL MIDDLETON \\ Oregon State University, Corvallis, OR
}

\begin{abstract}
Students at U.S. colleges and universities are concerned about the high cost of textbooks. Expansion of library course reserves has been suggested as one solution to this problem. The authors surveyed libraries at public universities to explore the status and management of physical course reserves and the role they play vis-à-vis textbook affordability. Both size and circulation of physical course reserve collections are declining. Despite a large growth in the use of electronic reserves, physical reserves play a significant role in providing textbooks for recommended reading lists. Physical course reserves represent a safety valve for students looking for ways to pay for college in an environment of ever-increasing textbook costs.
\end{abstract}

KEYWORDS Textbooks, textbook affordability, course reserves, mid-sized university libraries, survey, staffing, publishers, college book stores

\section{INTRODUCTION}

American academic libraries have offered course reserves services dating as far back as the 19th century, when history professors supplied the libraries at the University of Michigan, Harvard University, and Johns Hopkins University with lists of books their students would need during the semester (Austin, 2004). Course reserve services have since provided students with access to

Address correspondence to John H. Pollitz, Director of Libraries, University of WisconsinEau Claire, 105 Garfield Ave., Eau Claire, WI 54701. E-mail: pollitjh@uwec.edu 
class materials, which may take the form of books, photocopied articles, textbooks, class notes, old tests, and video or sound recordings.

The authors would not have thought about investigating the status of physical course reserve services had it not been for a wakeup call we received from an article published in the campus student newspaper. The Daily Barometer (Heartman, 2005) reported on a proposal that had been presented to the faculty senate by the Associated Students of Oregon State University (ASOSU). The students were very concerned about the rising cost of textbooks and looked to the library as a source of relief. Their proposal called for two copies of every assigned textbook to be put on reserve in the library as one solution for coping with highly inflated textbook costs.

According to a 2005 report by the Government Accountability Office (GAO), students spend on average $\$ 900$ a year on textbooks. Textbook costs have historically been a contentious issue for students (U. S. Government Accountability Office, 2005). Students and many other groups investigating textbook affordability believe university libraries have a role in helping to mitigate the high cost of textbooks. Reports on the issue of textbook costs from groups in several states as well as at the federal level have suggested that textbooks should be on reserve in the library (Illinois Board of Higher Education, 2005; State of Connecticut, 2006; State Council of Higher Education for Virginia, 2006; Advisory Committee on Student Financial Assistance, 2007; Minnesota Office of Higher Education, 2007, University of Wisconsin System, 2007; NYPIRG, 2008). These recommendations do not acknowledge the costs for libraries of providing expanded reserve services in terms of budget, space, and staffing. Only the report from the Minnesota Office of Higher Education (2007) addressed these issues in any fashion by stating that "faculty can be encouraged to support library expenses for the placement of textbooks on library reserve" (p. 11). Costs are an enormous issue. A recent textbook reserve project at the University of Illinois had to be abandoned because of high costs (Laskowski, 2007).

The ASOSU proposal inspired the authors to ask questions about the library's physical course reserves service (Pollitz \& Christie, 2006). What were the implications in terms of budget and staffing if the OSU Libraries adopted the students' recommendation for alleviating textbook costs? Are course reserves sustainable and still relevant in today's academic climate? What does it cost to run a course reserve service? Is providing a reserve service the most effective use of these funds? Questions about our own course reserves service prompted us to wonder how other libraries were managing their services and how librarians viewed the interplay between course reserve services and the high cost of textbooks.

There is little current literature on how physical course reserve services are being used. In the past 10 years, with the development and adoption of electronic reserve services (e-reserves), library literature has focused on that topic with very little attention paid to traditional paper-based reserve services. 
There is also little current information on the cost of providing the physical course reserve service, including the purchase of books and other items to go on reserve and library staff time to manage the reserve collection. We found only three articles reporting results from surveys of libraries on physical course reserve services conducted within the past 20 years. Gyeszley (1988) surveyed member libraries of the Association of Research Libraries (ARL) in autumn 1987 asking about reserve materials, staffing, and policies. After several years of observing a decline in the course reserve collection at the University of Denver, Fisher (1988) surveyed a group of academic libraries to investigate whether the use of commercial photocopying of class notes might be a factor. More recently, Tolppanen (2004) surveyed college and university libraries in an attempt to identify the current and future primary tasks of access services departments, and reported that nearly $50 \%$ of respondents expected faculty use of all reserve services to increase. At the same time, only $27 \%$ expected student use of physical reserve services to increase, and $44 \%$ expected it to decline. In a case study of the reserve collection at Rutgers University in 2004, Warner (2005) looked at the cost per use of books purchased for reserves, noting differences between disciplines as defined by Library of Congress call numbers.

We undertook a survey of peer institutions with two goals in mind. First, we wished to obtain a snapshot in time describing the state of physical course reserves services in a digital environment where e-reserve systems are becoming the primary means of supporting supplemental course readings. In light of the current crisis in textbook affordability, physical course reserve services have been suggested as a means of mitigating the costs that our students face. Our second goal was therefore to discover if libraries were positioned to make changes in course reserves in order to offer increased access to textbooks.

\section{METHODOLOGY AND SURVEY RESPONSE RATE}

To identify institutions to survey, we consulted the Carnegie Foundation for the Advancement of Teaching Classifications custom listings database (Carnegie Foundation, 2008). Selecting research-intensive, 4-year public institutions with enrollments over 10,000 undergraduate students resulted in a list of 196 universities similar to Oregon State University. We used the World Wide Web to identify the name and e-mail address of the Head of Access Services at each institution. Where we were unable to find a Head of Access Services, we looked for the Head of Circulation or the Head of Reserves to respond on behalf of their library. If it was not possible to identify a single contact for a particular university it was removed from the group, reducing the final list to 190 institutions. 
With the survey population determined, we developed questions for an online survey working with staff from the Oregon State University Survey Research Center. In order to achieve a high rate of return and obtain useful data, our survey asked for statistics we believed that libraries would have close at hand. The survey comprised 30 questions in the following categories: physical course reserves, electronic course reserves, textbooks and course reserves, budget and staffing, and demographics (see Appendix). The survey was announced by e-mail in August, 2006. A reminder message was sent after 2 weeks, and the survey was closed after 4 weeks. One hundred and five libraries responded to the first question in the survey. All but one of the libraries had course reserve services. Twenty libraries stopped answering the survey after the first two questions. This left a group of 84 libraries that completed the survey, resulting in a response rate of $44 \%(84 / 190)$.

Although the focus of our research was directed at libraries' physical course reserves services, we included questions about e-reserves in order to better evaluate the role of traditional services in the modern context. Ninety-six percent (80/83) of the responding libraries have an e-reserves system, indicating that this service has become ubiquitous. Ninety-five percent $(76 / 80)$ of these libraries responded that e-reserves had been in place for at least 2 years or more.

In reporting the survey results we present information on course reserves services in general followed by more specific aspects concerning textbooks in course reserves. We conclude with a discussion of the importance and future of physical course reserves in connection with textbook affordability and new digital technologies.

\section{SIZE AND CIRCULATION OF PHYSICAL COURSE RESERVES COLLECTIONS}

Physical course reserves collections at the responding libraries are not large. Sixty-eight percent (57/84) had fewer than 2000 items on reserve each semester or term, 13\% (11/84) had collections of 2000-4000 items, while 17\% (14/84) had collections exceeding 4000 items (see Figure 1). In Gyeszley's 1987 survey, 58 libraries (74\%) reported reserve collections exceeding 4000 items (Gyeszley, 1988). Our survey, conducted almost 20 years later, found traditional physical reserve collections considerably smaller. Thirty libraries (36\%) had fewer than 500 items in their reserve collection. It should be noted that, although Gyeszley's survey was sent solely to ARL libraries and ours to a broader group of academic libraries, there were similarities in the size of responding campuses. Over half of Gyeszley's group, 37 of 78 libraries, were from campuses with a student population below 20,000. This was very similar to the universities in our survey where 50 of 79 had student populations below 20,000. 


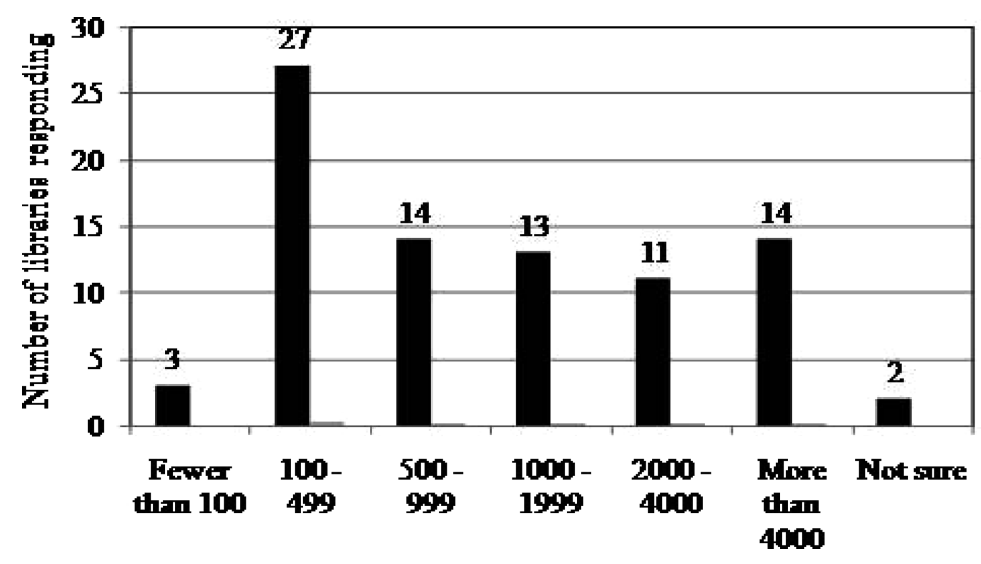

FIGURE 1 Number of items on physical reserve per semester or term.

When asked to consider the size of the physical course reserves collection in the preceding 5 years, the majority of libraries $(70 \%, 58 / 84)$ said the collection was decreasing (see Figure 2). The overwhelming reason given for the decrease of the physical course reserves collection was the implementation of e-reserves. In the 56 voluntary comments received in response to this question, 40 libraries said that the library's e-reserves service accounts for declining numbers of journal articles and book chapters placed on physical course reserves.

Circulation of the physical course reserves collection has also decreased in the preceding 5 years (see Figure 2). Fifty-five percent (46/84) of libraries reported a decrease, with one library noting a 50\% decrease in the previous decade. While some libraries commented that the decline in circulation did not apply to course textbooks or to media, many libraries directly related the decrease in circulation to the decrease in size of the physical reserves collection. Of the 58 libraries that said that the physical course reserves
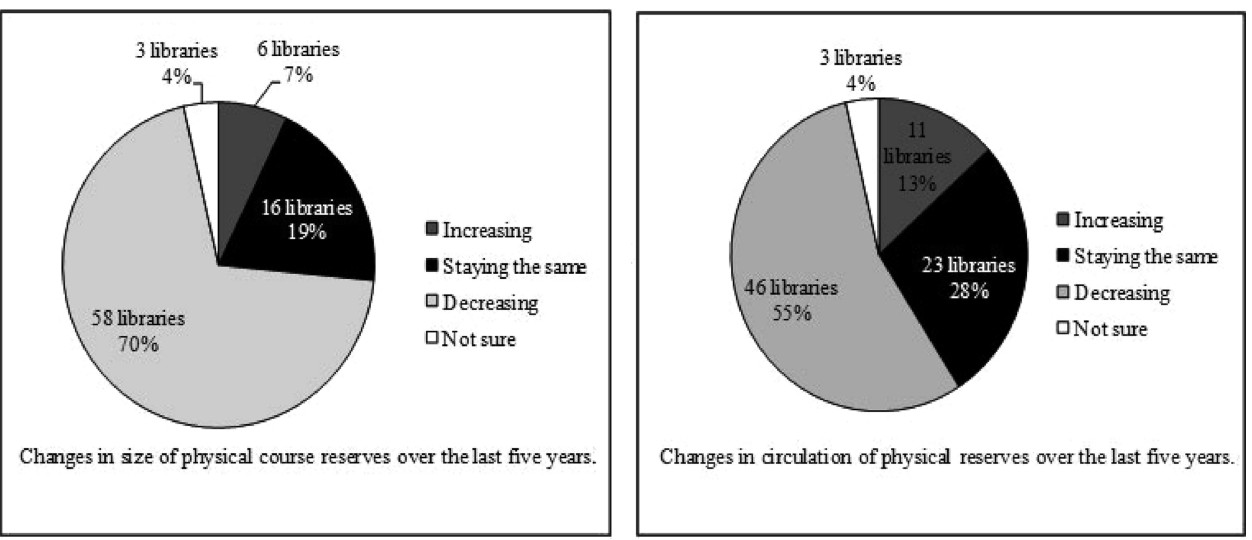

FIGURE 2 Changes in size and circulation of physical reserves over the last 5 years. 
collection was decreasing in size, 71\% (41/58) noted that circulation was also decreasing. Reasons given for the decrease in circulation included the campus bookstore selling course packs, the library no longer putting single articles on physical reserve, and new faculty who were unaware of physical course reserves services. The most common reason given for the decrease in circulation of the physical reserves collection, however, was the development of e-reserves, which have an advantage over physical course reserves in providing 24/7 access. A 1998 study of e-reserves supported the contention that students seem more willing to read reserve material when it is available online (Colaric, 1998). Some libraries noted very heavy use of e-reserves; in one case topping 300,000 hits in a year. It is difficult to imagine this volume of service at a physical course reserves desk.

\section{CONTENT AND OWNERSHIP OF RESERVE COLLECTIONS}

When we asked libraries to indicate the most abundant material type in their physical reserves collections, we received some surprising answers. While $49 \%$ (40/81) of respondents reported that the largest number of items on reserve was books, unexpectedly 40\% (32/81) reported that journal articles comprised the largest portion of their reserves collection. Earlier research had predicted that many libraries with e-reserve services would soon no longer need to maintain a physical reserve service (Tolppanen, 2004). We expected that, in an e-reserves world, few library physical reserve collections would be dominated by journals. Material particularly suited to e-reserves such as class notes and old/practice tests still represented a large segment of the physical reserves collection; for six libraries it was the largest part.

Our survey also investigated ownership of the books being placed on reserve. Eighty-five percent (70/84) of libraries responding to this query reported that their course reserve collections consisted primarily of libraryowned books, with only 15\% (12/82) responding that faculty-owned books made up the largest portion. Once again, our data differed from Gyeszley's 1987 findings in which reserve collections were "likely to have an almost equal number of library-owned and personal materials on reserve" (Gyeszley, 1988).

Libraries were asked their opinion about which disciplines put the most material on course reserves. Sixty-seven percent (52/78) of the responses indicated that the physical course reserves service was most heavily used by the arts and humanities (see Figure 3). Given the large amount of reading typically assigned in English, history, and philosophy classes, this is not unexpected. For the e-reserves collection the amount of use by the arts and humanities and the social sciences was about the same. We were somewhat surprised by the low use of reserve services by science and engineering. Is less reading required for students in science and engineering than for 


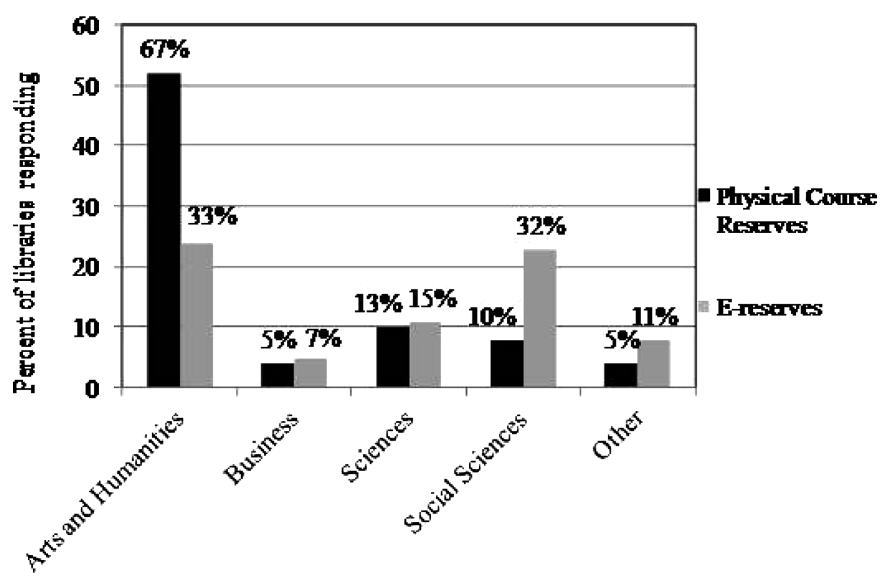

FIGURE 3 Use of course reserves by discipline.

students in the arts and humanities? Are science students more likely to purchase required and/or recommended textbooks than students in other disciplines? The second question is particularly intriguing considering that science textbooks are more expensive than for the humanities (Baker \& Taylor, 2008). Are science instructors more likely to post journal articles in course management systems or on their own Web sites? These issues represent fruitful areas for more investigation and data gathering, which could lead to a different allocation of library resources and services.

\section{COST OF STAFFING COURSE RESERVES SERVICES}

In designing our survey we attempted to make it easy to complete by asking for statistics we believed that libraries would have readily available. When it came to staffing and financial information, however, we did not always receive precise information. As a result, in these areas, we had a smaller subset of data from which to draw conclusions. Libraries reported a range of staffing numbers from a high of 30 to a low of 0.25 FTE. We cannot compare these numbers with Gyeszley's staffing data, which was reported for all libraries as a single group (Gyeszley, 1988). In our analysis, cost estimates for salaries that did not logically match staffing numbers were eliminated. Thirty-seven libraries in our survey used the same staff for physical course reserves and e-reserves, so they did not itemize the staffing costs for each service. In those cases we did not use the financial data. After winnowing out responses we arrived at a set of costs for physical course reserves (n28) and e-reserves (n23). The range of annual salary expenditures on 

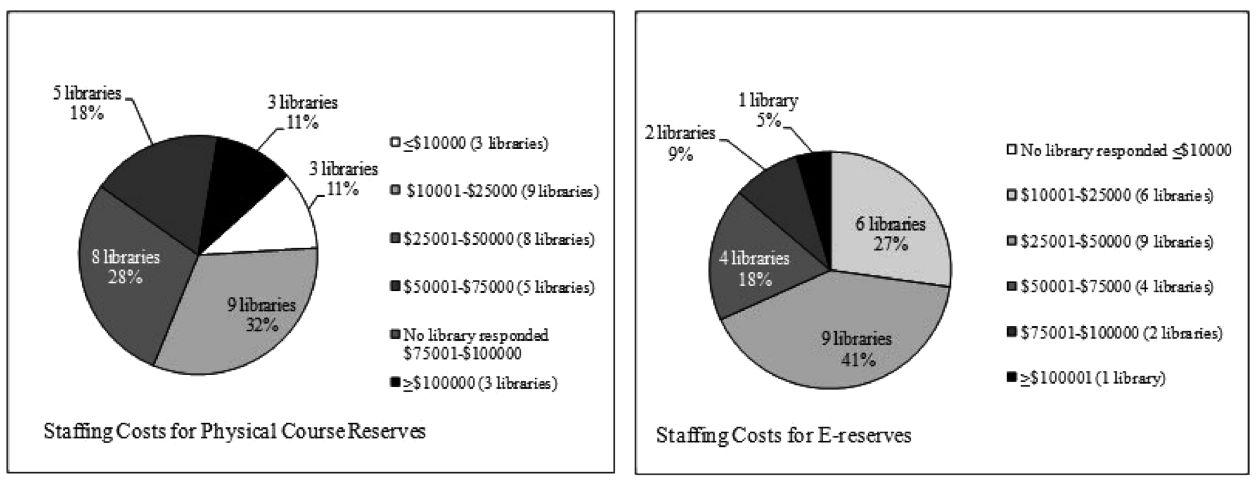

FIGURE 4 Staffing costs per year for physical course reserves and e-reserves.

physical course reserves ran from a high of $\$ 150,000$ to a low of $\$ 1,000$ (see Figure 4).

For e-reserves, the annual high was also $\$ 150,000$ (a different university than the one reporting this cost for physical course reserves) to a low of $\$ 10,000$ (see Figure 4.). Forty-seven percent (39/84) of the group spent between $\$ 25,000$ and $\$ 75,000$ on salaries for physical course reserves. Surprisingly, 31\% (26/84) spent between $\$ 75,000$ and $\$ 100,000$ to staff the physical reserves service. The numbers for e-reserves salaries also held some surprises. The majority of libraries, 64\% (14/22), that responded were spending in the $\$ 10,000$ to $\$ 50,000$ range on salaries. There were fewer libraries spending over $\$ 100,000$ on e-reserves than on physical course reserves. While these data are not precise enough to allow definitive conclusions, they suggest that future case studies in this area could provide valuable information upon which library administrations could make organizational decisions on managing reserve services.

The majority of libraries responding $(96 \%, 75 / 78)$ reported that they were the unit with primary responsibility for posting material on e-reserves. Faculty, however, can also play a large role in populating e-reserve services, potentially reducing involvement of reserves staff. Of the 75 institutions where libraries posted e-reserve material, 71\% (50/75) responded that faculty also post material. Comments from libraries where faculty have an active role in e-reserves indicate that those faculty are mainly posting documents in course management systems or on their own Web sites. A few libraries mentioned their role in assisting faculty by helping prepare material for posting on course management systems. Two others utilized the campus course management system to provide course readings online rather than paying for a separate library software product. Respondents to our survey indicated that information technology (IT) departments, academic departments, and copyright offices generally did not play a significant role in posting e-reserves. 


\section{TEXTBOOKS IN THE PHYSICAL COURSE RESERVE COLLECTION}

At Oregon State University students indicated that they saw the library's course reserve service as a source of relief from high textbook costs (Heartman, 2005). Our survey therefore investigated whether course reserve services were fulfilling this need nationwide. What were libraries doing to assist students as they faced rapidly increasing costs for textbooks? We wondered about the status of recommended textbooks in relationship to required textbooks. If students see recommended textbooks as less central to their class work, are recommended textbooks thus more of a burden to purchase? We therefore asked libraries to indicate whether recommended textbooks or required textbooks made up the majority of their reserve collections. Sixtyfour percent (52/81) of libraries that responded reported that recommended textbooks made up the largest part of their physical reserves collection, while for 31\% (25/81) of the libraries responding the number of required textbooks made up the largest portion. Reasons for the larger number of recommended books in course reserves could be that faculty expect students to purchase the required textbooks and do not place them on reserve and that libraries are less willing to purchase required textbooks as opposed to recommended books.

If libraries are going to commit to assisting students grappling with textbook affordability, they will need to reexamine their textbook-purchasing policies. In order to assess their current commitment to physical course reserve, we asked how many libraries actually purchased textbooks for their course reserve collections. We found that the majority of libraries still refrained from buying textbooks, even for reserves. Sixty-seven percent $(56 / 84)$ of the libraries responding to our survey did not buy any required textbooks, and 52\% (44/84) did not buy any recommended textbooks for course reserves. Of the libraries that do purchase textbooks, 47\% (39/84) bought some or all of the recommended books that instructors requested. In contrast, only $32 \%(27 / 84)$ of the libraries responding purchased some or all of the required books that instructors requested. Most of the libraries (14) purchased 39 or fewer required textbooks each semester or term but a few libraries (3) purchased more than 100 required textbooks for course reserves. Only 4 libraries purchased all of the textbooks that faculty requested.

Intimately related to the number of textbooks purchased by libraries for physical reserve collections is the cost of those books. Our survey attempted to tease out some information on the cost of maintaining a course reserve service presently, assuming that those costs would increase significantly if libraries decide to view physical course reserves as a way to provide relief to students from the high cost of textbooks. We asked libraries, "Please select the amount that most closely matches the amount spent for the physical course reserve service in a fiscal year," and to indicate whether the funds came from the general materials budget or if there was a specific fund 


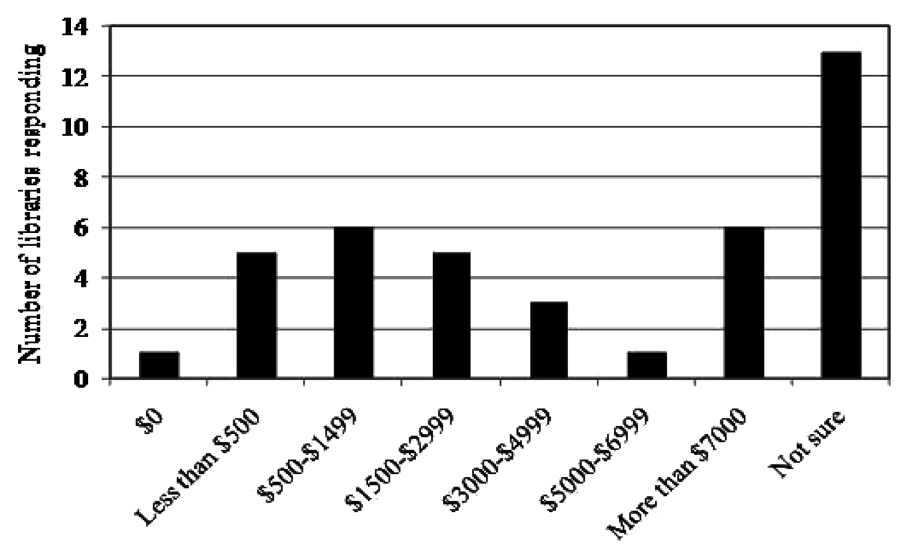

FIGURE 5 Dollars spent on physical course reserves in a fiscal year.

designated for course reserve material. Of the 39 libraries that reported purchasing material for course reserves, 44\% (17/39) spent less than $\$ 3000$ (see Figure 5). One third of the libraries (13/39) were uncertain about how much was spent each year to purchase material for the physical course reserves service. Of those libraries that purchase material, 38\% (15/40) had a specific budget line specifically for course reserves, 23\% (9/40) used general collection development funds lines, and 36\% (14/40) had no specific line. Six libraries responded that they spent in excess of $\$ 7000$ annually for course reserve material. Not surprisingly, four of the six indicated that they had a dedicated course reserves budget line. Furthermore, five of the libraries spending more than $\$ 7000$ on course reserves had student populations of over 25,000 FTE.

That two thirds of libraries responding to our survey did not buy required textbooks for course reserve collections at all supports the results of an earlier study reporting that libraries do not generally collect textbooks (Hsieh \& Runner, 2005). Reasons given by the libraries in our survey for not purchasing textbooks include the high cost, poor quality, processing time, rapid obsolescence, the need to purchase other materials for faculty research and curriculum support, and the belief that it is the students' responsibility to purchase their textbooks. Other libraries stated that the purpose of course reserves is to provide supplementary material for additional study or reinforcement rather than textbooks. Along this same line, one library noted that it does not borrow textbooks via interlibrary loan.

\section{ROLE OF THE LIBRARY IN PROVIDING ACCESS TO TEXTBOOKS}

Students are very concerned about the high cost of textbooks (Fairchild, 2004; State of Connecticut, 2006; State Council of Higher Education for Virginia, 
2006). Many of the libraries responding to this survey are aware that students have difficulty affording their textbooks and recognize a potential role for libraries in mitigating student costs. One library noted that while reserves circulation as a whole was down, the circulation of textbooks within this collection had increased. Librarians are also conscious of a common student complaint about textbooks; that often only a few chapters from the books are assigned and yet students must purchase the entire book. Respondents were also concerned that the cost of textbooks might lead instructors to scale back on required reading, potentially reducing the rigor of the college educational experience.

Some individual libraries in our survey have adopted various strategies to provide students with expanded access to textbooks via course reserves. These include:

- Increasing the number of textbooks on open/closed reserve.

- Developing a textbook collection in addition to course reserves.

- Purchasing textbooks in response to requests from students as well as faculty.

- Changing a policy for purchasing lower-division textbooks to cover upperdivision textbooks as well.

- Putting required and recommended books on reserve if owned by the library even if faculty have not made reserve requests.

- Purchasing textbooks for course reserves using academic department funds but also using library funds for purchasing some items for extended reserve.

Given the concern and actions of students on the Oregon State University campus with respect to textbooks, we also asked other libraries if they or any other group on campus had taken steps other than course reserves to address the textbook affordability issue. By "course reserves" we mean the traditional service where some faculty initiate reserve requests to provide students with access to assigned reading. Almost two thirds of the responding libraries $(64 \%, 50 / 78)$ had not considered any other approaches. Many libraries reported that while they have wrestled with the problem of adding textbooks to the collection, they had not come up with solutions. Both the cost of the textbooks and the space to house them are considerable obstacles. Because of the temporal nature of textbooks, purchasing them is not often seen as a good investment. Other concerns expressed about providing textbooks included competition with the private sector, violation of the university's contract with a textbook vendor, and pressure from the campus bookstore. A small number of libraries reported investigating electronic textbooks, but at the time of our survey they were not being widely adopted. One library responded that while the library was not involved in assisting students with access to textbooks, it was possible that other units on campus 
were. One library noted "there is a textbook scholarship program located at the Black Cultural Center where any student can apply for and check out textbooks for a semester," while another commented that, "the Associated Students are pushing for faculty to place personal copies of textbooks on course reserves."

\section{IMPORTANCE OF THE COURSE RESERVES SERVICE}

Libraries that responded to our survey serve undergraduate populations of 10,000 students and more. The prevailing attitude expressed by these libraries was that course reserves are a very important service for supporting students. Seventy-one percent $(56 / 79)$ of libraries stated that the physical course reserves service is essential, while $82 \%$ (60/73) stated that an e-reserves service is essential. When asked why they felt so strongly that reserve services were so important, several reasons were given. Many felt that course reserves are a backup source for textbooks that often present problems beyond their high cost. Textbooks often take a long time to acquire, older editions go out of print, bookstores run out of stock, and the books are sometimes supplemental rather than required in course syllabi. Many students can only afford the required texts when additional readings or references are prohibitively expensive (Advisory Committee on Student Finances, 2007). One library stated "by providing a course reserves service we are keeping an active role in the academic community on campus. Staff at the Reserves desks interact with faculty on a daily basis and provide a service that is highly valued by students who do not have extra cash to buy books and also want online access to as many readings as possible."

While students value the ease of desktop access to assigned reading and prefer it to spending time in the library, rights issues may mean that physical reserve collections will be around for some time to come. Many universities are still troubled by copyright rulings in the last decade that have resulted in fewer course packs being produced. Several libraries mentioned that course reserve services provide a legal source for students to access materials, such as journal articles, book chapters, and conference proceedings. On one campus, the teaching faculty use reserves services heavily specifically because the library handles copyright issues.

Several libraries remarked on changes in conditions on their campuses that have contributed to a decrease in course reserve collections and use. Some observed that there were more adjunct faculty employed on their campuses and that these faculty make fewer requests to place materials on reserve. Large class sizes caused faculty to be reluctant about assigning as much as outside reading as they once did. A number of comments expressed the feeling that students are less willing to do the reading for a class and less is being expected of them in terms of the amount and caliber of work required 
for their programs. These issues are not new to the digital environment. An earlier survey done in 1988 reflects many of the same concerns (Fisher, 1988).

Given the decrease in the size of the physical reserves collection, one library found it hard to argue that course reserves still represents an essential service. Another said "If we were to do away with it [course reserves] most students won't notice ..." "[S]ince electronic reserves could be done via courseware (and some professors do this)," replied one respondent, "course reserve services are therefore not an essential service, although much appreciated and heavily used." Yet another stated the belief that because of copyright a physical reserve collection will persist but that managing ereserves might move to other campus units, reducing the role of the library in supplying class readings.

\section{FUTURE OF COURSE RESERVES AND TEXTBOOK AFFORDABILITY}

In a rapidly shifting library world, it is difficult to provide a completely upto-date and comprehensive report of the state of academic library course reserves. Our survey collected national data that documents what many libraries were experiencing in their local environment at a specific point in time. Although a severe economic downturn and advances in digital publishing have impacted that environment in the intervening years, the observations and responses remain relevant and enlightening to libraries as they struggle with responding to student service expectations. Many librarians anticipate the continued decline in the physical reserves as e-reserves expand and as faculty members make more use of course management systems. One respondent's opinion was that there would be no traditional reserve collection within 5 years, although others projected that a small physical reserves collection will remain for items where electronic access is not feasible. As the reserve collection migrates to digital formats, the benefits of library services that are place bound and constricted by building hours have diminished. It is also likely that the processing and linking to digital collections may be managed by other campus units.

While other librarians have looked at the operations of course reserve services and use of the collections (Fisher, 1988; Colaric, 1998; Austin, 2004; Warner, 2005), our survey indicated that there is often not a clear understanding of the costs of this service. Many librarians responsible for reserve services were not sure what is being spent to purchase reserve material. Staffing costs are clouded by multiple job responsibilities and reporting structures. In the current economic atmosphere, awareness of library operational costs is of critical importance. As librarians make decisions regarding their role in solving the textbook-cost dilemma, the costs of providing or even expanding course reserve services must be carefully evaluated. We suggest, as 
did Warner (2005), that more case studies are needed as models for looking closely at the cost of providing course reserves.

Our study indicates lack of detailed knowledge regarding costs involved in providing a physical course reserves service. It is important that libraries better monitor the costs of this service and gain a better understanding of how it is used within the context of textbook affordability. Several libraries commented that the physical reserve collection was underused, yet students are looking to course reserves as a strategy for cutting their costs. As librarians pay more attention to data on how course reserves are being used and paid for, they can make better informed decisions about the organization and management of these services. Course reserve data will not only assist library managers but also the university as a whole. One library, for example, noted that the size of the course reserves collection per department and its use was part of the departmental accreditation process.

The forces contributing to shrinking physical course reserve collections should be tracked with an eye toward these questions. Will there be a time when these collections no longer represent a core library service?" Will escalating textbook costs ensure the life of physical reserve collections into the foreseeable future? Can or should the resources that support traditional physical course reserves services be redirected or expanded to focus more strongly on textbook affordability for students who are confronting the cost of today's college education? What effect will new electronic publishing ventures have on textbook costs and the use of physical course reserves? The question of purchasing textbooks remains a topic of discussion for college libraries, as reflected in a recent flurry of messages on the collib-1 LISTSERV (Pellegrino, 2009).

The current textbook economic environment is in flux. Costs are rising, students are upset, publishers are defensive, and campus bookstores are in a crunch between the two. University administrators are hearing from parents and the government. Libraries come into the picture through course reserve services, both physical and electronic. The future role for libraries in this environment remains uncertain and ill-defined. The libraries that replied to our survey commonly do not purchase textbooks. State governments, like Minnesota, have looked at solutions to the cost of textbooks and have noted the role of libraries in addressing this cost to students. The comments we received indicated that, at the time, while many librarians were aware of what the high cost of textbooks means to students on their campuses, they had not explored alternatives that their libraries might offer for students facing increasing textbook costs.

On a national level librarians are making textbooks and textbook-cost inflation their concern. At the American Library Association (ALA) Midwinter Conference in January 2009, the Association of College and Research Libraries (ACRL) and Scholarly Publishing and Academic Resources Coalition (SPARC) held a joint ACRL-SPARC Forum entitled, "The Transformative Potential of Open Educational Resources (OER)." A panel, representing 
faculty, college bookstores, and student groups, discussed open-source and commercial electronic textbook initiatives that promise to lower student costs and the role libraries play in this burgeoning movement (Belliston, 2009). Meetings such as these help librarians keep informed on the development of electronic textbooks that could have a major impact on physical course reserves. A new commercial player recently entered the electronic textbook market when Amazon announced the Kindle DX as a platform for providing textbooks (Stone \& Rich, 2009). Six colleges and universities will be testing out the new Kindles during the next academic year. Another university, Northwest Missouri State University (NMSU), has already been experimenting with electronic textbooks and downloading texts onto laptop computers (Gross, 2009; Young, 2009) NMSU has had a textbook rental service since 1905 and all students now receive a notebook computer (Northwest Missouri State University, 2009). Over the 2008/2009 academic year, 500 students tested out electronic book readers and digital textbooks on their notebooks.

While some universities are learning how electronic textbooks can help keep costs down, others, like North Carolina State University (NCSU), are working to address the textbook-cost issue in the print format. Midway into the fall 2008 semester, the NCSU Libraries began making at least one copy of every required textbook, over 3,000 books, available in their physical course reserve system. Each textbook can be checked out for a 2-hour period (North Carolina State University, 2009). In response to a student proposal, the university library has been working in collaboration with the campus bookstore to provide this service. The library has committed about $\$ 250,000$ of their collections budget to the program and they have seen a 600\% rise in reserve circulation (Vaughn, 2009). One librarian at NCSU described the program as a successful collaboration between the library and the campus bookstore, addressing not only the cost of textbooks but also their size. Having textbooks on reserve frees students from the need to load their backpacks full of heavy books for a day of classes. The campus bookstore was enthusiastic about working with the library and did not see the program as a threat to their operation, noting that it was responsive to student needs and that because of competition for a limited number of books and 2hour circulation periods, they felt that students would continue to purchase required textbooks (T. Reade, personal communication, June 24, 2009).

While academic libraries are facing one of the most severe funding crises in decades, our students and their families are also facing economic exigencies that are forcing make-or-break decisions about their education. Some help may be on the way in the form of the current national economic stimulus package that includes $\$ 29$ billion to make college more affordable. Along with increases in direct aid through Pell Grants and Federal Work Study, the package will make textbook costs an eligible part of taxpayers' education tax credit (Supiano, 2009). The severe downturn in the global economy and technological innovations will continue to impact all academic library services and the students that use them. Physical course reserves are 
in the middle of the very prominent textbook-affordability crisis. Our survey, a snapshot in time, is the only recent study to query medium-size academic libraries regarding managing print material and textbooks in course reserve services. More investigation is needed regarding how the economy is impacting physical course reserves, and certainly on how electronic textbooks will affect this traditional service.

\section{ACKNOWLEDGEMENTS}

We thank Karyle Butcher, University Librarian at Oregon State University, for supporting this project with a grant from the Friends of OSU Libraries, our colleagues for their input and review, staff at the OSU Survey Research Center for advice on the survey design, and the librarians across the country who responded.

\section{REFERENCES}

Advisory Committee on Student Financial Assistance. (2007). Turn the page: Making college textbooks more affordable. Retrieved June 24, 2009, from http://www.ed.gov/about/bdscomm/list/acsfa/turnthepage.pdf

Austin, B. (2004). Reserves, electronic reserves, and copyright: The past and the future. Binghamton, NY: Haworth Information Press.

Baker \& Taylor. (2008). New Title Reports. Retrieved May 7, 2009, from http://www.ybp.com/TitleReports08/YBP_0708_LC_Subject_UP.xls

Belliston, C. J. (2009). Open educational resources: Creating the instruction commons. College and Research Libraries News, 26, 284-287, 303.

Carnegie Foundation for the Advancement of Teaching. (2008). Custom listings. Retrieved June 24, 2009, from http://www.carnegiefoundation.org/ classifications/index.asp?key $=784$

Colaric, S. M. (1998). Students who do not currently read traditional reserve readings and their attitudes toward electronic reserve. Unpublished Masters thesis, University of North Carolina at Chapel Hill. (ERIC Document Reproduction No. ED418716). Retrieved May 7, 2009, from http://www.eric.ed.gov/ ERICDocs/data/ericdocs2sql/content_storage_01/0000019b/80/15/68/55.pdf

Fairchild, M. (2004). Ripoff 101: How the current practices of the textbook industry drive up the cost of college textbooks. California Student Interest Research Group. Retrieved June 24, 2009, from http://www.immagic.com/eLibrary/ ARCHIVES/GENERAL/ST_PIRGS/C040127F.pdf

Fisher, P. A. (1988). Is reserve a jeopardized service in academic libraries? A position paper. (ERIC Document Reproduction Service No. ED328273). Retrieved May 7 , 2009, from http://www.eric.ed.gov/ERICWebPortal/Home.portal?_nfpb=true\& ERICExtSearch_SearchValue_0 = ED328273\&ERICExtSearch_SearchType_0 = no\&_ pageLabel=ERICSearchResult\&newSearch=true\&rnd=1250633100210\&searchtype =keyword 
Gross, S. M. (2009, February 23). Paper cut: Missouri college embraces e-textbooks. NPR Morning Edition. Retrieved June 24, 2009, from http://www.npr.org/ templates/story/story.php?storyId=99961163

Gyeszley, S. (1988). Reserve departments and automation: A survey of ARL libraries. Information Technology and Libraries, 7, 401-410.

Heartman, H. (2005, October 10). Hitting the books hard on wallets. The Daily Barometer (Oregon State University), p. 3.

Hsieh, C., \& Runner, R. (2005). Textbooks, leisure reading, and the academic library. Library Collections, Acquisitions, and Technical Services, 29, 192-204.

Illinois Board of Higher Education Student Advisory Committee. (2005). Textbook affordability recommendations. Retrieved June 24, 2009, from http://www. ibhe.state.il.us/Board/agendas/2005/August/SAC\%20textbook\%20item.pdf

Laskowski, M. S. (2007). The textbook problem: Investigating one possible solution. Library Collections, Acquisitions, and Technical Services, 31, 161-170.

Minnesota Office of Higher Education. (2007). Strategies for reducing students' textbook costs. Retrieved June 24, 2009, from http://www.ohe.state. mn.us/pdf/textbookCostsReport.pdf

North Carolina State University. (2009). Frequently asked questions: Do you have textbooks? Retrieved June 24, 2009, from http://www.lib.ncsu.edu/ faq/faq.php?id=24

Northwest Missouri State University. (2009). About the initiative. Retrieved June 24, 2009, from http://www.nwmissouri.edu/services/eTextbooks/about.htm

NYPIRG. (2008). Sticker shock 101: Faculty opinions about textbook prices, publishers' tactics and efforts to rein in textbook prices. Retrieved June 24, 2009, from http://www.nypirg.org/highered08/reports/StickerShock101.pdf

Pellegrino, C. (2009, June 10). Re: textbook collection policies. Message posted to collib-l electronic mailing list, archived at http://lists.ala.org/sympa/arc/collib1/2009-06/msg00051.html

Pollitz, J. H., \& Christie, A. (2006). The high cost of textbooks: A convergence of academic libraries, campus bookstores, publishers? E-JASL: Electronic Journal of Academic and Special Librarianship, 7(2). Retrieved May 7, 2009, http://southernlibrarianship.icaap.org/content/v07n02/pollitz_j01.htm

State Council of Higher Education for Virginia. (2006). A report on textbooks purchasing practices and costs in the Commonwealth. Retrieved May 7, 2009, from http://www.schev.edu/Reportstats/2006TextbookStudy.pdf

State of Connecticut, Department of Higher Education, Board of Governors for Higher Education. (2006). A report to the joint standing committee of the General Assembly having cognizance of matters relating to higher education and employment advancement, Special Act No. 04-3, an Act concerning student textbook purchasing policies. Retrieved May 7, 2009, from http://www.ctdhe.org/info/pdfs/2006/2006TextbookReport.pdf

Stone, B., \& Rich, M. (2009) Amazon introduces big-screen Kindle. New York Times, May 6, 2009, online issue. Retrieved June 21, 2009, from http://www. nytimes.com/2009/05/07/technology/companies/07kindle.html?_r=1\&scp=1\& sq $=$ kindle $\% 20$ textbooks \&st $=$ cse

Supiano B. (2009, March 6). The billion-dollar question: Which students benefit? The Chronicle of Higher Education. 55, 26, A22-23. 
Tolppanen, B. B. (2004). A survey of current tasks and trends in access services. Journal of Access Services, 2, 1-14.

U. S. Government Accountability Office. (2005). College textbooks enhanced offerings appear to drive recent price increases. (GAO-05-806). Washington, DC: U.S. Government Printing Office. Retrieved June 24, 2009, from http://www.gao.gov/new.items/d05806.pdf

University of Wisconsin System, Office of Operations Review and Audit, Program Review. (2007). Textbook costs in higher education. Retrieved June 24, 2009, from http://www.uwsa.edu/audit/textbookcosts.pdf

Vaughn, A. (2009, February 9). Textbooks available on reserve: Student proposal initiates change in library. Technician Online (North Carolina State University). Retrieved June 24, 2009, from http://www.technicianonline.com/news/textbooksavailable-on-reserve-1.1358568

Warner, D. (2005). Where does the money go? Rutgers University Library tracks reserve collection purchases. Journal of Access Services, 3, 17-26.

Young, J. (2009, June 12). 6 lessons one campus learned about e-textbooks. The Chronicle of Higher Education. 55, 39, A18. 


\section{APPENDIX}

\section{Informed Consent}

In your capacity as Head of Circulation or Access Services we are requesting your assistance through this invitation to complete this 30 question online survey assessing your perceptions on the use and economy of physical Course Reserves collections within your library. The results of the survey will help us update the understanding of the utility of Physical Course Reserve Collections in university libraries and be published in a scholarly journal.

All surveys are anonymous and confidential. No names or e-mail addressed will be solicited on the survey. If you choose to fill out the survey, there are no foreseeable risks to you. There are also no direct benefits associated with your participation in this study. Participation is entirely voluntary. You may skip any item you do not wish to answer, or stop answering questions at any time. If you agree to participate in this online survey, we estimate that the survey will take approximately $15-20$ minutes to complete.

Please print out and retain this informed consent document for future reference.

If you have any questions about the study procedures or the survey, please contact the principal investigator:

John H. Pollitz, Oregon State University Libraries

(541) 737-8527

John.Pollitz@oregonstate.edu

Co-Investigators:

Anne Chrisite, Oregon State University Libraries (541) 737-7291

Anne.Christie@oregonstate.edu

Cheryl Middleton, Oregon State University Libraries

(541) $737-7273$

Cheryl.Middleton@oregonstate.edu

If you have any questions about your right as a research participant, please contact:

The OSU Institutional Review Board Administrator (IRB)

(541) $737-4933$

IRB@oregonstate.edu

* 1. 1. Indicate your agreement below. If you don't wish to participate, simply close your browser.

I agree to participate in the survey.

\section{Physical Course Reserves}

\section{Does your library have a Course Reserves service?}

res

No 


\section{Physical Course Reserves}

3. How many items are typically placed in the physical Course Reserves collection each semester or term?

Fewer than 100
$100-499$
$500-999$
$1000-1999$
$2000-4000$
More than 4000
Not sure

4. Please rank order the number of items typically placed in the physical Course Reserves collection, with 1 indicating the smallest number of items and 5 indicating the largest number of items.

Books
Journal articles
Audiovisual items
Class materials, e.g.,
class notes and
previous tests
Other; e.g. physical
objects, realia, rocks,
bones

1 (SMALLEST)

$\bigcirc$

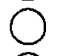

$\bigcirc$

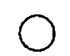

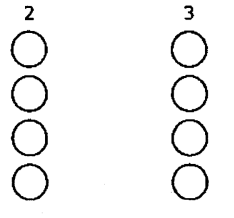

$\bigcirc$

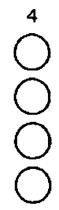

5 (LARGEST)<smiles>O</smiles><smiles>O</smiles><smiles>c1ccccc1</smiles><smiles>O</smiles>

0

5. Please rank order the number of items typically placed in the physical Course Reserves collection, with 1 indicating the smallest number of items and 5 indicating the largest number of items.

$\begin{array}{lcccc}\text { Books owned by the } & 1 \text { (SMALLEST) } & \text { 2 } & \text { 3(LARGEST) } & 0 \\ \begin{array}{l}\text { library } \\ \text { Books owned by }\end{array} & 0 & 0 & 0 & 0 \\ \begin{array}{l}\text { instructors } \\ \text { Books owned by } \\ \text { academic departments }\end{array} & 0 & 0 & 0 & 0\end{array}$

6. Please rank order the number of items typically placed in the physical Course Reserves collection, with 1 indicating the smallest number of items and 5 indicating the largest number of items.

$\begin{array}{lcc}\text { Required class } & 1 \text { (SMALLEST) } & 2 \text { (LARGEST) } \\ \text { textbooks } & \bigcirc & \bigcirc \\ \text { Recommended class } & 0 & 0 \\ \text { texts } & 0 & \end{array}$

N/A

O

texts 
7. Does your library purchase required textbooks for the physical Course Reserve collection?

Yes, all textbooks that are requested by instructors

Yes, some textbooks that are requested by instructors

No

Not sure

\section{9 yes}

8. What is the typical number of required textbooks purchased per semester or term?

Less than 10

10-39

40-59

(60-79

$80-99$

More than 100

$\bigcirc$ Not sure

Other (please specify)

\section{9 No}

9. Does your library purchase recommended class texts for the physical Course Reserves system?

Yes, all recommended class texts that are requested by instructors

Yes, some recommended class texts that are requested by instructors

$\bigcirc$ No

Not sure 


\section{Purchase recommended class texts}

10. What is the typical number of recommended class texts purchased per semester or term?
Less than 10
10-39
40-59
60-79
80-99
More than 100
Not sure
other (please specify)

\section{Budget Questions}

11. Are there specific budget lines for books that are purchased for the physical Course Reserve collection?
Yes-Reserves budget line
Yes - General collection development funds
No specific budget line
Not sure

12. Please select the amount that most closely matches the amount spent for the physical Course Reserve system in a fiscal year.
\$0
Less than $\$ 500$
\$500-1499
\$1500-2999
\$3000-4999
\$5000-6999
More than $\$ 7000$
Not sure 
8. Physical Course Reserves Usage

13. Please estimate the linear footage that the physical Course Reserve collection occupies.

14. Looking at the past 5 years would you say that the size of the physical Course Reserves collection is increasing, staying the same, or decreasing?
Increasing
Staying the same
$\bigcirc$ Decreasing
Not sure

15. Please comment on any changes.

16. Looking at the past 5 years would you say that circulation of the physical Course Reserves collection is increasing, staying the same, or decreasing?
Increasing
staying the same
Decreasing
Not sure

17. Please comment on any changes.

9. Electronic Reserves Questions

18. Does your university have a system for posting electronic class readings, e.g., course management, e-reserves systems?

Yes

No 


\section{Electronic Reserves Questions}

19. Please indicate which of the following is responsible for electronic posting of class readings. (Check all that apply)

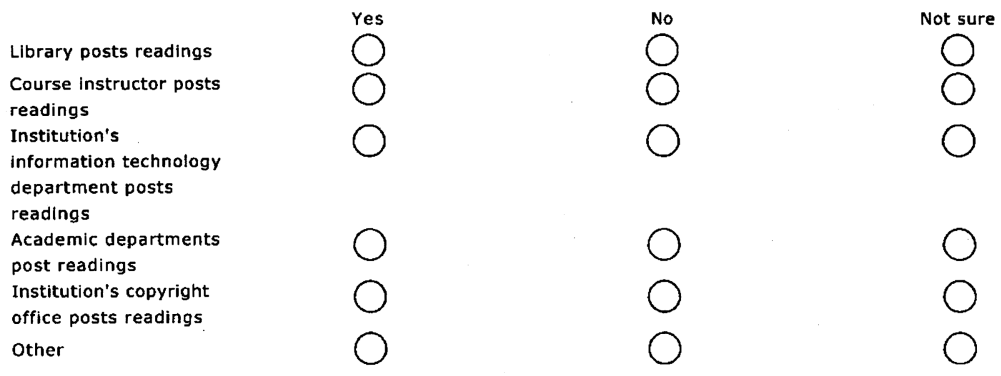

20. Please comment on answer above.

21. If your library has an electronic Course Reserves system, when was it implemented?

within the past 2 years

Within the past 2.5 years

More than 5 years ago

other (please specify) 
11. Staffing Course Reserves: Physical and Electronic

22. Approximately, how many staff and students are involved in providing the Course Reserves service? (Please consider both your physical Course Reserve collection and your Electronic Reserves collection if you have an Ereserve service)

Staff FTE Physical

Staff FTE E-reserve

Students FTE Physical

Students FTE E-reserve

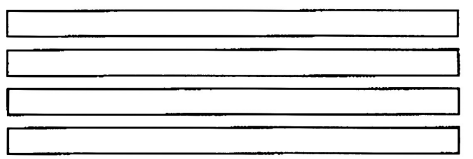

23. Please estimate the total salary cost per fiscal year for the staff and student time indicated above. (Please consider both your physical Course Reserve collection and your Electronic Reserves collection if you have an Ereserve service)

Staff Physical Course

Reserve

Staff E-reserve

Students Physical

Course Reserve

Students E-reserve

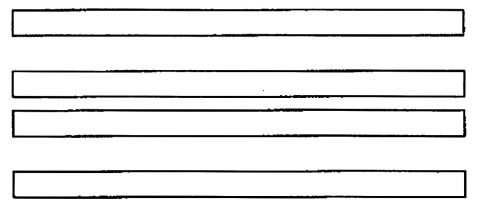

24. Click on the discipline which, in your opinion, places the most material on physical Course Reserves and in e-reserves in the library.

$\begin{array}{lcccccc} & \begin{array}{c}\text { Arts and } \\ \text { Humanities }\end{array} & \text { Business } & \text { Engineering } & \text { Sciences } & \text { Social Sciences } & \text { other } \\ \text { Physical Course } & 0 & 0 & 0 & 0 & 0 & 0 \\ \text { Reserves } & 0 & 0 & 0 & 0 & 0 & 0\end{array}$

25. Please comment on above answer if you checked "other".

26. In your opinion, how important is the Library's physical Course Reserve service or e-reserves in providing an academic resource for students?

Physical collection

27. Please comment on your answers above.

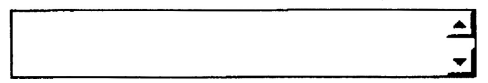




\section{Final Questions}

28. Has your library or campus considered other alternatives to Course Reserves for providing students with access to required textbooks?

No

Yres

$\bigcirc$ Please Describe

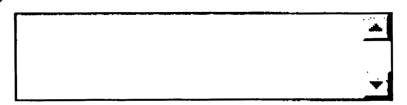

29. What is the size of the undergraduate population on your campus?

Less than 10,000

10,000-14,999

15,000-19,999

$\bigcirc 20,000-25,000$

More than 25,000

30. What else would you like to say about Course Reserves systems in your library?

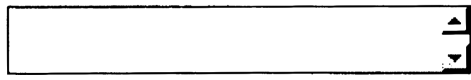

